\title{
АНАЛІТИЧНІ АСПЕКТИ МІЖЛАБОРАТОРНОГО КОНТРОЛЮ ЯКОСТІ РЕЗУЛЬТАТІВ ЕЛЕМЕНТНОГО АНАЛІЗУ В БІОЛОГІЧНИХ СЕРЕДОВИЩАХ ЛЮДИНИ
}

Вступ. У роботі розглянуто питання аналізу мікроелементного складу сироватки і цільної крові людини як важливий момент проведення клінічної діагностики. Стандартні зразки біологічних матеріалів є повноцінним носієм правильності та прецесійності вимірювання.

Мета дослідження - дати порівняльну оцінку правильності та прецесійності визначення макро- $i$ мікроелементів у тестовій сироватці й цільній крові методом багатоелементного аналізу оптико-емісійної спектрометрії з індуктивно зв'язаною плазмою.

Методи дослідження. Зразки сироватки крові на вміст $\mathrm{Na}, \mathrm{K}, \mathrm{Ca}, \mathrm{Mg}$, Fe, Cu, Zn, P та цільної крові на вміст Pb, Cd, Mn, Se готували відповідно до валідованої і затвердженої методики. Дослідження проводили на приладі оптико-емісійної спектрометрії з індуктивно зв'язаною плазмою моделі Optima 2100 DV фрірми "Perkin-Elmer" (США).

Результати й обговорення. Дослідження з визначення 8-ми хімічних елементів у сироватці крові за програмою “Sequas" (FORTRESS), які проводили впродовж року, продемонстрували велику кількість добрих (6) та задовільних (4) результатів з 12-ти визначень. Найбільша кількість високих збігів під час участі в програмі "LAMP" (CDC) була характерна для Mn i Se, менша - для Cd ma Pb. Визначено методологічні підходи для отримання адекватних результатів, наприклад застосування коефіцієнта поправок та прийомів корекції спектральних завад. Описано особливості використання рефрерентних зразків для проведення міжлабораторних тестів і контролю якості досліджень вмісту макро- та мікроелементів у біологічних середовищах. Показано перспективність застосування сучасних спектральних методів багатоелементного аналізу в клінічній діагностиці мікроелементозів.

Висновок. Участь у програмах міжлабораторних порівнянь дозволяє вдосконалювати власні внутрішні процедури контролю якості визначення макро- та мікроелементів у біологічних середовищах, дає додаткову зовнішню оцінку випробувальних спроможностей лабораторій і, таким чином, підвищує надійність отриманих результатів лабораторної діагностики.

КЛЮЧОВІ СЛОВА: макро- і мікроелементи; стандартні зразки біологічних матеріалів; референтні значення; міжлабораторний контроль якості.

ВСТУП. Найважливішим напрямком екології людини та гігієни навколишнього середовища $€$ розробка високоінформативних методів діагностики змін у стані здоров'я людини у зв'язку 3 високою забрудненістю навколишнього середовища. Одним з напрямків первинної та вторинної профрілактики захворювань $є$ адекватна діагностика мікроелементозів, основана насамперед на точному кількісному визначенні елементів в індикаторних біосубстратах людини [1-4]. Однак у сучасній системі біологічного моніторингу та клінічних діагностичних досліджень мікроелементів відсутній єдиний підхід до вирішення комплексу завдань, що стоять перед аналітиками. Міжнародний досвід показує, що в більшості

(c) І. М. Андрусишина, І. О. Голуб, О. Г. Лампека, 2019. випадків результати аналітичних вимірювань важко порівняти між собою через застосування різних методик підготовки біологічних зразків, аналітичних інструментів, умов відбору і зберігання проб, прийнятих в окремих регіонах "норм" вмісту хімічних елементів [4-8]. Комітет з поліпшення навколишнього середовища (CEI) Американського хімічного товариства запропонував рекомендації щодо вибору методів і процедури виконання аналітичних вимірювань, які регламентують основні етапи аналітичного процесу при вивченні мікроелементного складу об'єктів природи [3, 6]. 3 огляду на це, доцільними $€$ розробка, уніфікація та валідація сучасних методик визначення як пріоритетних потенційно небезпечних токсичних хімічних речовин, так і 
життєво необхідних хімічних елементів для вдосконалення системи біомоніторингу. Крім того, при проведенні клінічних діагностичних досліджень потрібно враховувати метрологічні показники, які забезпечують правильність, відтворюваність, збіжність і точність вимірювання кількості хімічних елементів у біологічних зразках.

У реальних умовах важливим моментом "хорошої" лабораторної практики може бути внутрішній і міжлабораторний контроль якості досліджень елементного складу біологічних зразків. Стандартні зразки біологічних матеріалів $€$ повноцінним носієм правильності та прецесійності вимірювання [1-2]. Однак вони характеризуються значним впливом неінформативних параметрів (домішок, структури матеріалу та ін.). Відомі стандартні зразки біологічних матеріалів (цільної крові, волосся, сухого молока, печінки) обмежені за складом хімічних елементів (серед виробників таких стандартних зразків - Австрія, Бельгія, США та Китай), часто не доступні через високу ціну для ряду лабораторій України. Участь у програмах міжлабораторних порівнянь дозволяє вдосконалювати власні внутрішні процедури контролю якості лабораторних досліджень, надаючи додаткову оцінку їх випробувальних спроможностей та верифрікації методик.

Мета дослідження - дати порівняльну оцінку правильності та прецесійності визначення макро- і мікроелементів у тестовій сироватці й цільній крові методом багатоелементного аналізу оптико-емісійної спектрометрії з індуктивно зв'язаною плазмою.

МЕТОДИ ДОСЛІДЖЕННЯ. Лабораторія аналітичної хімії та моніторингу токсичних речовин нашого інституту має багаторічний досвід участі в різних міжлабораторних порівняннях як об'єктів довкілля, так і біологічних середовищ. Так, у 2014 р. співробітники лабораторії брали участь у таких дослідженнях впродовж 6 місяців, а у 2015 р. - протягом року. Вміст $\mathrm{Na}, \mathrm{K}, \mathrm{Mg}, \mathrm{Ca}, \mathrm{Cu}$, $\mathrm{Fe}, \mathrm{Zn}$ i P у сироватці крові людини визначали як у тестовому матеріалі, так і в референтному зразку ("норма" і "патологія") за програмою "Sequas" (FORTRESS, Англія). У 2017 і 2018 рp. брали участь у міжлабораторних порівняннях за програмою "LAMP" (CDC, CША) з визначення вмісту Pb, Cd, Mn та Se в цільній крові як у тестовому матеріалі, так і в референтному зразку. Дослідження проводили на приладі оптико-емісійної спектрометрії з індуктивно зв'язаною плазмою (ОЕС-ІЗП) моделі Optima 2100 DV фірми "Perkin-Elmer" (США). Зразки сироватки крові готували відповідно до методики [9]. Отримані результати досліджень статистично оброблено згідно з [10].
РЕЗУЛЬТАТИ Й ОБГОВОРЕННЯ. В ОстаННі роки в лабораторній діагностиці широко застосують різні спектральні методи: атомно-абсорбційний (ПААС, ЕТААС), атомно-емісійний з індуктивно зв'язаною плазмою (АЕС-ІЗП або OEC-ІЗП), мас-спектрометричний з індуктивно зв'язаною плазмою (МС-ІЗП) та ін. Ці методи мають високу чутливість для визначення макро(MaE) та мікроелементів (ME). Однак якість лабораторних досліджень повинна відповідати вимогам аналітичної точності, встановленим нормативам їх вмісту в біологічних середовищах, що $€$ обов'язковою умовою надійної роботи клінічних лабораторій. Незважаючи на постійне вдосконалення інструментальних засобів, що мають високу точність, якість кінцевих результатів лабораторних аналітичних досліджень і контроль фрізико-хімічних та біологічних параметрів залишаються низькими. Згідно з результатами дослідження Міжнародної фредерації клінічної хімії, частка "клінічно неправильних" результатів при проведенні діагностичних досліджень коливається в межах від 17 до $50 \%$.

На підставі отриманих лабораторних даних лікар визначає стратегію лікування, тому якість останніх повинна бути гарантована. Достовірні лабораторні дані можна одержати за допомогою референтних зразків з різними концентраціями. Важливо, щоб оцінка результатів проведеного аналізу відповідала ряду метрологічних показників конкретного методу вимірювання.

У цьому дослідженні при налагодженій методиці виконання вимірювань у лабораторії інституту повторні вимірювання однієї і тієї ж проби сироватки крові (програма "Sequas") коливалися в межах діапазону прийнятих ресрерентних значень (табл. 1). При погіршенні правильності вимірювання за даною методикою всі результати були змінені в бік збільшення або зменшення результатів встановленого середнього значення. Таким чином, збільшувалося розсіювання результатів (при цьому погіршувались відтворюваність, правильність методики вимірювання). Для цілей клінічної діагностики на практиці вводили коефіцієнт похибки. Для точності результатів вимірювань одним із важливих метрологічних показників $€$ правильність вимірювань.

У ході порівняльного аналізу стандартного зразка сироватки крові з прописаними референтними значеннями ("норма") програми "Sequas" їм найбільш відповідав вміст K, Cu i Zn (табл. 2). У другому випадку (“патологія") - K, Mg, P і Zn (табл. 3). Вимірювання вмісту мікроелементів у біологічних середовищах має свої особливості, які визначаються методологічними підходами до кожного етапу проведення робіт [4-6]. Метроло- 
Таблиця 1 - Результати аналізу стандартного сертифрікованого зразка сироватки

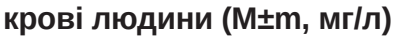

\begin{tabular}{|l|c|c|c|c|c|c|}
\hline \hline Елемент & $\begin{array}{c}\text { Сертифрікована } \\
\text { концентрація }\end{array}$ & $\begin{array}{c}\text { Допустимий } \\
\text { діапазон відхилень }\end{array}$ & $\begin{array}{c}\text { Знайдено } \\
\text { в 1-й репліці }\end{array}$ & $\begin{array}{c}\text { 3найдено } \\
\text { у 2-й репліці }\end{array}$ & $\begin{array}{c}\text { Середнє } \\
\text { значення }\end{array}$ & $\begin{array}{c}\text { 3біжність, } \\
\%\end{array}$ \\
\hline $\mathrm{Ca}$ & $105,90 \pm 6,10$ & $99,8-112,0$ & 104,4 & 103,93 & $104,16 \pm 0,47$ & 98,36 \\
\hline $\mathrm{Mg}$ & $21,10 \pm 3,60$ & $17,5-24,7$ & 21,07 & 21,28 & $21,18 \pm 0,11$ & 100,38 \\
\hline $\mathrm{Cu}$ & $0,76 \pm 0,15$ & $0,61-0,90$ & 0,75 & 0,77 & $0,76 \pm 0,02$ & 100,0 \\
\hline $\mathrm{Fe}$ & $2,40 \pm 0,40$ & $2,0-2,8$ & 2,26 & 2,22 & $2,24 \pm 0,04$ & 93,33 \\
\hline $\mathrm{Zn}$ & $0,37 \pm 0,06$ & $0,31-0,43$ & 0,36 & 0,35 & $0,36 \pm 0,01$ & 97,30 \\
\hline $\mathrm{P}$ & $37,70 \pm 6,80$ & $30,9-43,9$ & 38,0 & 37,24 & $37,62 \pm 0,38$ & 99,79 \\
\hline
\end{tabular}

Таблиця 2 - Деякі метрологічні показники вимірювання хімічних елементів у тестовому зразку ("норма")

\begin{tabular}{|l|c|c|c|c|}
\hline $\begin{array}{c}\text { Елемент та } \\
\text { довжина хвилі, } \\
\text { нм }\end{array}$ & $\begin{array}{c}\text { Межа визначення при } \\
\text { rad/aх огляді плазми, } \\
\text { мг/л }\end{array}$ & $\begin{array}{c}\text { Діапазон } \\
\text { ресрерентних } \\
\text { значень, мг/л }\end{array}$ & $\begin{array}{c}\text { Отриманий } \\
\text { результат, мг/л }\end{array}$ & $\begin{array}{c}\text { Правильність } \\
\text { вимірювання, \% } \\
\text { P=0,95 }\end{array}$ \\
\hline $\mathrm{Ca}, 317,933$ & $0,003(\mathrm{ax})$ & $99,8-112,0$ & $88,75-109,40$ & $88,93-97,68$ \\
\hline $\mathrm{Mg}, 279,077$ & $0,00003(\mathrm{ax})$ & $17,5-24,7$ & $17,63-21,73$ & $100,74-87,98$ \\
\hline $\mathrm{K}, 766,490$ & $0,001(\mathrm{rad})$ & $130,2-182,6$ & $129,4-181,0$ & $99,39-99,12$ \\
\hline $\mathrm{Na}, 589,592$ & $0,0005(\mathrm{rad})$ & $2735,6-3839,2$ & $2333,00-3711,25$ & $85,28-96,67$ \\
\hline $\mathrm{P}, 213,617$ & $0,004(\mathrm{ax})$ & $30,9-43,9$ & $31,00-45,44$ & $100,32-103,51$ \\
\hline $\mathrm{Cu}, 324,752$ & $0,0003(\mathrm{ax})$ & $0,61-0,90$ & $0,56-0,97$ & $91,80-107,78$ \\
\hline $\mathrm{Fe}, 259,939$ & $0,0003(\mathrm{ax})$ & $2,0-2,8$ & $1,51-2,26$ & $75,50-80,71$ \\
\hline $\mathrm{Zn}, 206,200$ & $0,0004(\mathrm{ax})$ & $0,31-0,43$ & $0,30-0,45$ & $96,77-104,65$ \\
\hline
\end{tabular}

Таблиця 3 - Деякі метрологічні показники вимірювання хімічних елементів у тестовому зразку ("патологія")

\begin{tabular}{|l|c|c|c|c|}
\hline $\begin{array}{c}\text { Елемент та } \\
\text { довжина хвилі, } \\
\text { нм }\end{array}$ & $\begin{array}{c}\text { Межа визначення при } \\
\text { rad/aх огляді плазми, } \\
\text { мг/л }\end{array}$ & $\begin{array}{c}\text { Діапазон } \\
\text { референтних } \\
\text { значень, мг/л }\end{array}$ & $\begin{array}{c}\text { Отриманий } \\
\text { результат, мг/л }\end{array}$ & $\begin{array}{c}\text { Правильність } \\
\text { вимірювання, \% } \\
\mathrm{P}=0,95\end{array}$ \\
\hline $\mathrm{Ca}, 317,933$ & $0,003(\mathrm{ax})$ & $95,0-133,5$ & $107,63-134,80$ & $113,29-100,97$ \\
\hline $\mathrm{Mg}, 279,077$ & $0,00003(\mathrm{ax})$ & $33,3-46,9$ & $31,19-46,92$ & $93,66-100,04$ \\
\hline $\mathrm{K}, 766,490$ & $0,001(\mathrm{rad})$ & $192,0-269,4$ & $194,20-263,93$ & $101,15-97,97$ \\
\hline $\mathrm{Na}, 589,592$ & $0,0005(\mathrm{rad})$ & $2489,7-3487,4$ & $2674,52-3504,00$ & $107,42-100,48$ \\
\hline $\mathrm{P}, 213,617$ & $0,004(\mathrm{ax})$ & $58,5-82,1$ & $56,50-84,96$ & $96,58-103,48$ \\
\hline $\mathrm{Cu}, 324,752$ & $0,0003(\mathrm{ax})$ & $0,95-1,33$ & $0,77-1,42$ & $81,05-106,77$ \\
\hline $\mathrm{Fe}, 259,939$ & $0,0003(\mathrm{ax})$ & $0,49-0,69$ & $0,41-0,64$ & $83,67-92,75$ \\
\hline $\mathrm{Zn}, 206,200$ & $0,0004(\mathrm{ax})$ & $0,45-0,65$ & $0,44-0,53$ & $97,78-81,54$ \\
\hline
\end{tabular}

гічне забезпечення таких досліджень повинно включати як наявність атестованих методик, процедури аналізу, так і використання стандартних біологічних матеріалів [2, 4, 6, 11].

Результати дослідження, яке проводили впродовж року, добре демонструють кількість добрих та задовільних результатів, що відповідали ресрерентним значенням (рис.). Кількість абсолютних збігів протягом року становила 6 (це 100,0 \% правильність вимірювання) 3 12-ти визначень, вище норми отримано 2 значення (3,0 \%), 4 значення були нижчими від норми (16,0 \%). Діаграми коливань значень для Zn y сироватці крові демонструють різне в часі збільшення або зменшення концентрації як за рефрерентними значеннями, так і за отриманим у лабораторії результатом.

Так, для Zn у сироватці крові високі значення виявлено влітку (6-8 місяців), низькі-в зимовий період (1, 2, 12 місяців). Це свідчить про те, що концентрація елемента в зимовий період може бути заниженою. Останнє потребує застосування коефріцієнта поправки, який без оцінки правильності вимірювання неможливо розрахувати.

Наступним етапом повірки якості лабораторних досліджень був досвід участі в програмі "LAMP". У цій програмі беруть участь понад 200 лабораторій світу. Кожного кварталу року лабораторіям надсилають цільну кров (зразки по 2 повторності для 3-х різних концентрацій) для визначення в ній вмісту $\mathrm{Pb}, \mathrm{Cd}, \mathrm{Mn}$ та Se. Iнтерпретацію отриманих результатів кожного раунду проводили з урахуванням середнього значення та величини стандартного відхилення з подальшою їх оцінкою за допомогою z-індексів за W. Horwitz [11, 12]. Z-індекс показував, яка кількість одержаних у лабораторії результатів була щодо атестованого значення доброю $(|z|<2)$, 


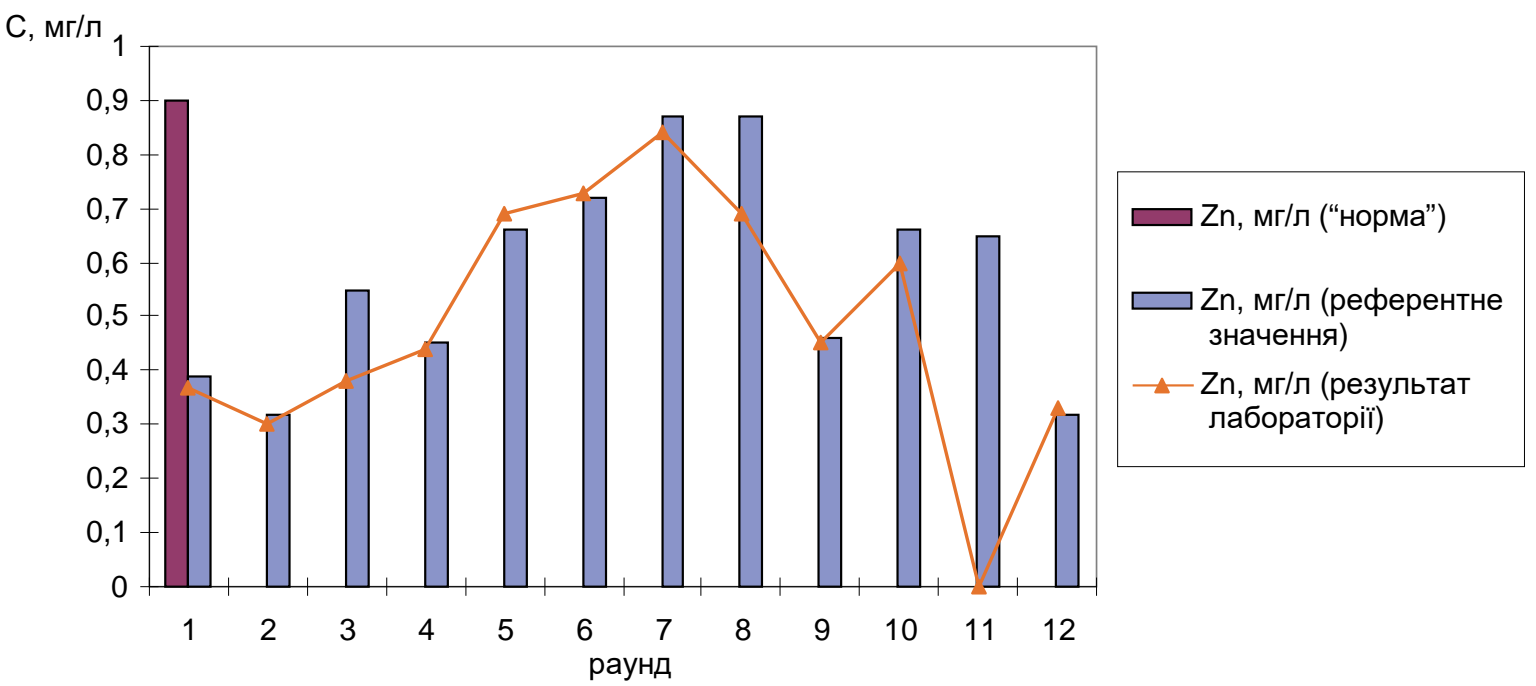

Рис. 1. Карта індивідуальних значень вмісту цинку в сироватці крові порівняно з прийнятою "нормою" та ресрерентним значенням у тестовому середовищі в динаміці року.

задовільною $(2<|z|<3)$ та сумнівною $(|z|>3)$. За 2 роки участі у 8-ми раундах отримано такі результати: для $\mathrm{Pb}-75,02 \%$ випадків добрих, 24,68 \% випадків задовільних та 0,3\% випадків сумнівних визначень; для $\mathrm{Cd}-72,0$ \% випадків добрих, $24,50 \%$ випадків задовільних і 0,3 \% випадків сумнівних визначень; для $\mathrm{Mn}-90,0$ \% випадків добрих та 10,0 \% випадків задовільних визначень; для Se - 75,0 \% добрих і 25,0 \% випадків задовільних визначень. Найбільша кількість високих збігів була характерна для $\mathrm{Mn}$ i Se, менша - для $\mathrm{Cd}$ та Pb. Для прикладу в таблиці 4 наведено результати 46 раунду програми "LAMP".

Раз на рік надається сертифрікований референтний зразок з відповідною концентрацією металів - $\mathrm{Pb}, \mathrm{Cd}$ та $\mathrm{Hg}$ для розрахунку коефіцієнта поправки. Так, для вмісту $\mathrm{Pb}$ у цільній крові ресрерентне значення становило величину $(19,80 \pm 0,02)$ мкг/л, а отримано результат $(20,00 \pm 0,18)$ мкг/л, що свідчило про відтворюва- ність 101,01 \%, яка відповідала метрологічним вимогам. Для $\mathrm{Cd}$ ресрерентний зразок цільної крові мав концентрацію $(1,90 \pm 0,38)$ мкг/л, а отримано результат $(2,10 \pm 0,50)$ мкг/л, що свідчило про відтворюваність 110,52 \%, яка відповідала метрологічним вимогам, але потребувала введення коефріцієнта поправки шляхом оцінки правильності вимірювання. Останнє виконують шляхом внесення 3-х різних концентрацій металу в зразок крові в діапазоні рефрерентних значень ("норми"). У нашому випадку для $\mathrm{Cd}$ цей коефріцієнт розраховано як 1,1. У ряді випадків під час вимірювання низьких концентрацій було застосовано методи корекції спектральних завад за допомогою математичних прийомів, вкладених у програмне забезпечення приладу моделі Optima 2100 DV - IES (міжелементна корекція спектра - метод корекції спектральних завад, застосовують тоді, коли немає повного накладання спектральних ліній елемента, який вимі-

Таблиця 4 - Порівняння отриманих у лабораторії результатів 46 раунду програми “LAMP” щодо вмісту металів у цільній крові з референтними значеннями CDC

\begin{tabular}{|c|c|c|c|c|}
\hline $\begin{array}{c}\text { Елемент та } \\
\text { довжина хвилі, } \\
\text { нм }\end{array}$ & $\begin{array}{c}\text { Межа визначення при } \\
\mathrm{rad} / \mathrm{ax} \text { огляді плазми, } \\
\text { мг/л }\end{array}$ & $\begin{array}{c}\text { Діапазон } \\
\text { рефрерентних } \\
\text { значень, мкг/л }\end{array}$ & $\begin{array}{c}\text { Отриманий } \\
\text { результат, мкг/л }\end{array}$ & $\begin{array}{c}\text { Правильність } \\
\text { вимірювання, \% } \\
\text { P=0,95 }\end{array}$ \\
\hline \multirow{3}{*}{$\begin{array}{l}\mathrm{Pb} \\
220,353\end{array}$} & \multirow{3}{*}{$0,001(a x)$} & $37,00 \pm 0,10$ & $42,00 \pm 0,80$ & 113,51 \\
\hline & & $23,00 \pm 0,10$ & $43,00 \pm 0,86$ & 186,96 \\
\hline & & $162,00 \pm 0,40$ & $141,00 \pm 2,82$ & 87,03 \\
\hline \multirow{3}{*}{$\begin{array}{l}\mathrm{Cd} \\
228,802\end{array}$} & \multirow[t]{3}{*}{0,00009 (ax) } & $4,10 \pm 0,10$ & $2,70 \pm 0,05$ & 65,86 \\
\hline & & $10,20 \pm 0,40$ & $4,20 \pm 0,08$ & 41,18 \\
\hline & & $2,10 \pm 0,10$ & $2,100 \pm 0,042$ & 100 \\
\hline \multirow{3}{*}{$\begin{array}{l}\mathrm{Mn}, \\
257,610\end{array}$} & \multirow[t]{3}{*}{0,00003 (ax) } & $7,70 \pm 0,20$ & $6,50 \pm 0,13$ & 84,41 \\
\hline & & $8,00 \pm 0,20$ & $5,70 \pm 0,11$ & 71,25 \\
\hline & & $6,30 \pm 0,20$ & $3,00 \pm 0,06$ & 47,62 \\
\hline \multirow{3}{*}{$\begin{array}{l}\text { Se, } \\
196,026\end{array}$} & \multirow[t]{3}{*}{0,003 (ax) } & $230,00 \pm 8,90$ & $260,80 \pm 5,22$ & 113,39 \\
\hline & & $242,00 \pm 11,70$ & $270,20 \pm 5,40$ & 112,65 \\
\hline & & $225,00 \pm 8,40$ & $262,30 \pm 5,25$ & 116,58 \\
\hline
\end{tabular}

Примітка. Виділені значення правильності вимірювання відповідають метрологічним вимогам. 
рюють, та елемента, що заважає його визначенню) і MSF (багатокомпонентна апроксимація спектрів - математичний прийом з використанням множинної лінійної регресії, який дозволяє відрізнити спектр елемента, який вимірюють, від спектра елемента, що заважає його визначенню).

ВИСНОВКИ. 1. Сучасна клінічна діагностика може потребувати одночасного визначення декількох металів у біологічному середовищі людини. У такому випадку бажано використовувати багатоелементні методи аналізу з низькими межами виявлення (в концентраціях від мг до нг).

2. Основним недоліком методичних підходів, які використовують при виконанні аналізу на вміст макро- та мікроелементів у біологічних середовищах людини, є застосування різнома- нітних спектральних приладів, методів, нормативів. Це ускладнює обґрунтування такого важливого поняття, як "норма", що обмежує клінічну діагностику мікроелементозів та оцінку стану здоров'я людини. Отримання “правильних результатів" під час визначення макро- та мікроелементів не можна очікувати, якщо аналізи не контролюють шляхом використання еталонних зразків.

3. Участь у програмах міжлабораторних порівнянь дозволяє вдосконалювати власні внутрішні процедури контролю якості визначення макро- та мікроелементів у біологічних середовищах, дає додаткову зовнішню оцінку випробувальних спроможностей лабораторій i, таким чином, підвищує надійність отриманих результатів лабораторної діагностики.

\section{СПИСОК ЛІТЕРАТУРИ}

1. Оберлис Д. Биологическая роль макро- и микроэлементов у человека и животных / Д. Оберлис, Б. Харланд, А. Скальный. - СПб. : Наука, 2008. -544 с.

2. Определение химических фором микроэлементов в биологических объектах / Н. Б. Иваненко, Н. Д. Соловьев, А. А. Иваненко, Л. М. Москвин // Аналитика и контроль. -2012. - 16, № 2. - С. 108-121.

3. Michalke B. Metallomics: Analytical Techniques and Speciation Methods. - John Wiley \& Sons. - 2016. $496 \mathrm{p}$.

4. Аналитические методы в биоэлементологии / А. В. Скальный, Е. В. Лакарова, В. В. Кузнецов, М. Г. Скальная. - СПб. : Наука, 2009. - 264 с.

5. Макаренко Ф. Т. Определение тяжелых металлов в некоторых органах, тканях и жидкостях человека в норме / Ф. Т. Макаренко, Т. В. Вознесенская, В. И. Меницкая // Суд. мед. экспертиза. - 2001. № 5. - C. 28.

6. Лисецкая Л. Г. Методологические вопросы анализа микроэлементов в биосредах / Л. Г. Лисецкая // Бюл. ВСНЦ СО РАМН. - 2005. - № 1 (39). С. $168-173$.

\section{REFERENCES}

1. Oberlis, D., Kharland, B., \& Skalnyy, A. (2008). Biologicheskaya rol makro- $i$ mikroelementov u cheloveka i zhyvotnykh [The biological role of macro- and microelements in humans and animals]. Saint Petersburg: Nauka [in Russian].

2. Ivanenko, N.B., Solovyev, N.D., Ivanenko, A.A., \& Moskvin, L.M. (2012). Opredeleniye khimicheskikh form
7. Федоров В. И. Современное состояние проблемы анализа неорганических элементов в сыворотке крови / В. И. Федоров // Клинич. лаб. диагностика. 2006. - № 4. - С. 8-14.

8. Коновалова С. О. Сравнение инорормативности изучения различных биосубстратов для мониторинга минерального обмена / С. О. Коновалова // Укр. биохим. журн. - 2002. - 4, № 4a. - С. 145-146.

9. Оцінка порушень мінерального обміну у профресійних контингентів за допомогою методу атомно-емісійної спектрометрії з індуктивно зв'язаною плазмою : метод. рек. 72.14/133.14 / [І. М. Андрусишина, О. Г. Лампека, І. О. Голуб та ін.]. - К. : Авіцена, 2014. - 60 c.

10. Антомонов М. Ю. Математическая обработка и анализ медико-биологических данных / М. Ю. Антомонов. - К. : ФМД, 2006. - 558 с.

11. Внутренний контроль качества результатов количественного химического анализа. - М. : ГОССТАНДАРТ России. - Утв. 10-01-03. - 65 с.

12. Проценко В. Н. Основы обеспечения качества клинических лабораторных исследований / В. Н. Проценко. - Х. : ІІВ, 2009. - 120 с.

mikroelementov $v$ biologicheskikh obyektakh [Determination of chemical forms of microelements in biological objects]. Analitika i kontrol - Analytics and Control, 16 (2), 108-121 [in Russian].

3. Michalke, B. (2016) Metallomics: Analytical techniques and speciation methods. John Wiley \& Sons. 
4. Skalnyy, A.B., Lakarova, E.V., Kuznetsov, V.V., \& Skalnaya, M.G. (2009). Analiticheskiye metody v bioelementologii [Analytical methods in bioelementology]. Saint Petersburg: Nauka [in Russian].

5. Makarenko, F.G., Voznesenskaya, T.V., \& Menitskaya, V.I. (2001). Opredeleniye tyazhelykh metallov v nekotorykh organakh, tkanyakh i zhydkostyakh cheloveka v norme [Determination of heavy metals in certain organs, tissues and human fluids in the norm]. Sud. med. ekspertiza - Journal of Forensic Medical Examination, 5, 28 [in Russian].

6. Lisetskaya, L.G. (2005). Metodologicheskiye voprosy analiza mikroelementov $v$ biosredakh [Methodological issues of analysis of trace elements in biological media] Byul. VSNTS SO RAMN - Bulletin of the East Siberian Scientific Center of the Siberian Branch of the Russian Academy of Medical Sciences, 1 (39), 168-173 [in Russian].

7. Fedorov, V.I. (2006). Sovremennoye sostoyaniye problemy analiza neorganicheskikh elementov $v$ syvorotke krovi [Current state of the problem of analysis of inorganic elements in blood serum]. Klin. lab. diagnostika Clinical Laboratory Diagnostics, 4, 8-14 [in Russian]

8. Konovalova, S.O. (2002). Sravneniye informativnosti izucheniya razlichnykh biosubstratov dlya monitoring mineralnogo obmena [Comparison of the informa- tiveness of studying various biosubstrates for monitoring mineral metabolism]. Ukr. biokhim. zhurn. - Ukrainian Biochemical Journal, 4 (4a), 145-146 [in Russian].

9. Andrusyshyna, I.M., Lampeka, O.H., Holub, I.O., Lubianova, I.P., \& Kharchenko, T.D. (2014). Otsinka porushen mineralnoho obminu u profesiinykh kontynhentiv za dopomohoiu metodu atamno-emisiinoi spektrometrii z induktyvno zviazanoiu plazmoiu [Evaluation of mineral metabolism disorders in professional contingencies for the additional method of atomic emissive spectrometry from inductively connected plasma]. Kyiv: Avitsena [in Ukrainian].

10. Antomonov, M.Yu. (2006). Matematicheskaya obrabotka i analiz mediko-biologicheskikh dannykh [Mathematical processing and analysis of biomedical data]. Kyiv: FMD [in Russian].

11. (2003). Vnutreniy kontrol kachestva rezultatov kolichestvennogo khimicheskogo analiza [Internal quality control of the results of quantitative chemical analysis]. Moscow: GOSSTANDART of Russia. Approved 10-01-03 [in Russian]

12. Protsenko, V.N. (2009). Osnovy obespecheniya kachestva klinicheskikh laboratornykh issledovaniy [Basics of quality assurance in clinical laboratory studies]. Kharkiv: IV [in Russian]

И. Н. Андрусишина, И. А. Голуб, Е. Г. Лампека ИНСТИТУТ МЕДИЦИНЫ ТРУДА ИМЕНИ Ю. И. КУНДИЕВА НАМН УКРАИНЫ, КИЕВ

\section{АНАЛИТИЧЕСКИЕ АСПЕКТЫ МЕЖЛАБОРАТОРНОГО КОНТРОЛЯ КАЧЕСТВА РЕЗУЛЬТАТОВ ЭЛЕМЕНТНОГО АНАЛИЗА В БИОЛОГИЧЕСКИХ СРЕДАХ ЧЕЛОВЕКА}

\section{Резюме}

Вступление. В работе рассмотрены вопросы анализа микроэлементного состава сыворотки и цельной крови человека как важный момент проведения клинической диагностики. Стандартные образцы биологических материалов являются полноценным носителем правильности и прецесийности измерения.

Цель исследования - дать сравнительную оценку правильности и прецесийности определения макро- и микроэлементов в тестовой сыворотке и цельной крови методом многоэлементного анализа оптико-эмиссионной спектрометрии с индуктивно связанной плазмой.

Методы исследования. Образцы сыворотки крови на содержание $\mathrm{Na}, \mathrm{K}, \mathrm{Ca}, \mathrm{Mg}, \mathrm{Fe}, \mathrm{Cu}, \mathrm{Zn}, \mathrm{P} \mathrm{u}$ цельной крови на содержание $\mathrm{Pb}, \mathrm{Cd}, \mathrm{Mn}$, Se готовили в соответствии с валидированной и утвержденной методикой. Исследования проводили на приборе оптико-эмиссионной спектрометрии с индуктивно связанной плазмой модели Optima 2100 DV фрuрмы "Perkin-Elmer” (США).

Результаты и обсуждение. Исследования по определению 8-ми химических элементов в сыворотке крови по программе "Sequas" (FORTRESS), которые проводили на протяжении года, продемонстрировали большое количество хороших (6) и удовлетворительных (4) результатов из 12-ти измерений. Найбольшое количество високих совпадений во время участия в программе "LAMP" (CDC) было характерно для Mn u Se, меньшее - для Cd u Pb. Опеределены методологические подходы для получения адекватных результатов, например использование коэфициента поправок и приемов коррекции спектральных помех. Описаны особенности использования рефрерентных образцов для проведения межлабораторных тестов и контроля качества исследований содержания макро- и микроэлементов в биологических средах. Показана перспективность применения современных спектральных методов многоэлементного анализа в клинической диагностике микроэлементозов. 
Вывод. Участие в программах межлабораторных сравнений позволяет совершенствовать собственные внутренние процедуры контроля качества определения макро- и микроэлементов в биологических средах, дает дополнительную внешнюю оценку испытательных возможностей лабораторий и, таким образом, повышает надежность полученных результатов лабораторной диагностики.

КЛЮЧЕВЫЕ СЛОВА: макро- и микроэлементы; стандартные образцы биологических материалов; референтные значения; межлабораторный контроль качества.

I. M. Andrusyshyna, I. O. Golub, O. G. Lampeka YU. KUNDIIEV INSTITUTE OF OCCUPATIONAL HEALTH OF THE NAMS OF UKRAINE, KYIV

\section{ANALYTICAL ASPECTS OF THE INTERLABORATORY QUALITY CONTROL OF THE RESULTS OF ELEMENT ANALYSIS IN HUMAN BIOLOGICAL MEDIA}

\section{Summary}

Introduction. The paper presents the analysis of the microelement composition of serum and the human whole blood as an important moment in clinical diagnostics. Standard samples of biological materials are a full-fledged carrier of correctness and precise measurement.

The aim of the study - to assess the correctness and precision of the determination of macro- (MaE) and microelements (ME) in the test serum and the whole blood by the method of multi-elemental analysis of opticallyemission spectrometry with inductively coupled plasma (OES-ICP).

Research Methods. Samples of blood serum on the content of $\mathrm{Na}, \mathrm{K}, \mathrm{Ca}, \mathrm{Mg}, \mathrm{Fe}, \mathrm{Cu}, \mathrm{Zn}, \mathrm{P}$ and those of the whole blood on the content of $\mathrm{Pb}, \mathrm{Cd}, \mathrm{Mn}$, Se were prepared according to the validated and approved method of optical emission-spectrometry with inductively coupled plasma (OES-ICP) on the Optima 2100 DV by Perkin-Elmer (USA).

Results and Discussion. Studies on determination of 8 chemical elements in blood serum under the Sequas program (FORTRESS), conducted throughout a year, demonstrated a high number of good (6) and satisfactory (4) results of 12 measurements. The largest number of high coincidences in the LAMP program were established for obtaining adequate results, such as the use of a correction factor and types of spectral interference correction. The peculiarities of using the reference samples for interlaboratory tests and for the quality control of MaE and ME content in biological media are underlined. The perspectives of using modern spectral methods of multi-element analysis in clinical diagnostics of microelementosis were described.

Conclusion. The participation in the programs of interlaboratory comparisons makes it possible to improve own internal procedures for monitoring the quality of determination of macro- and microelements in biological media, provides for an additional external assessment of the testing abilities of laboratories and, thus, increases the reliability of the results obtained in laboratory diagnostics.

KEY WORDS: macro- and microelements; standard samples of biological materials; reference values; interlaboratory quality control.

Адреса для листування: І. М. Андрусишина, Інститут медицини праці імені Ю. І. Кундієва НАМН України, вул. Саксаганського, 75 , Київ, 01033, Україна, е-mail: andrusyshyna.in@gmail.com. 